7-6. バックライト（橋本健 （株）東芝）

液晶ディスプレイ (LCD:Liquid Crystal Display)は、液晶 材料そのものが自己発光しないため、何らかの光源が必要 となる。

近年では、ノート型パーソナルコンピュータ（ノート PC）用の大型 LCD をはじめとして、光源にバックライト を用いた透過方式 LCD が主流となっている。

バックライトは、LCD モジュールの表示性能、消費電 力、厚さ、重量に直接影響を与え、その商品価值を決定す る重要な構成部品である。ここでは、ノート PC 用バック ライトの動向と、現在主流となっている蛍光ランプを用い た導光体方式バックライトの構成、および、これからのバ ックライトについて述べる。

7-6-1. ノート PC 用バックライトの動向

LCD 市場の売り上げの大半はノート PC 分野である。 その主流となっているカラー TFT-LCD はノート PC の 大きさをほとんど変えることなく、9.4.インチからスター トし、現在では 12.1 インチ、13.3 インチへと大型化して きた。そのなかでバックライトはノートサイズに収めるた めに、狭額縁化、薄型化、軽量化を進め、携帯機器として の低消費電力化を実現し、ノート PC の大画面化に大きく 貢擜してきた。

ノート PC 用途のカラー TFT-LCD モジュール用バッ クライトの技術トレンドを図 1 に示す。1 開発当初は図 2 のような 4 本の蛍光ランプを用いた直下方式で、厚さ $17 \mathrm{~mm}$ 、重量 $500 \mathrm{~g}$ 、消費電力 $9 \mathrm{~W}$ であったものが、現在で は1 本の监光ランプを用いた導光体方式で、厚さ $3.5 \mathrm{~mm}$ 、 重量 $140 \mathrm{~g}$ 、消費電力は $1 \mathrm{~W}$ を割ろうとしている。アレイ 開口率やセル性能の技術進歩により LCD セルの透過泳が 約 2 倍に向上しているが、バックライトはそれ以上に性能 向上してきたといえる。
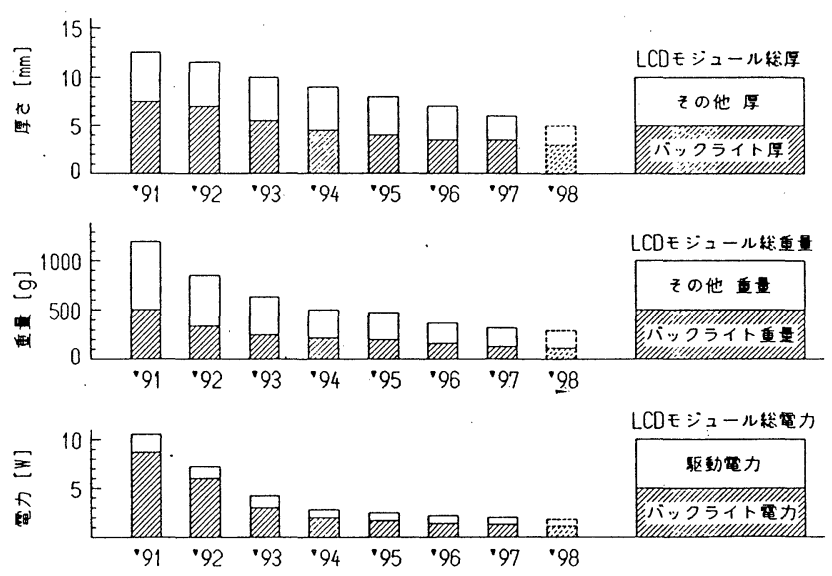

図 1.TFT-LCDモジュールの技術トレンド(10.41忓換算)
しかし、LCD モジュール全体に占めるバックライトの 厚さ、重量、消費電力の割合は、厚さで約 $2 / 3$ 、重量で 約 $1 / 2$ 、消費電力では約 $2 / 3$ 以上と依然大きい。図 3 に示すとおり、LCD モジュールにおけるエネルギー利用効 率は $1 \%$ にも満たない。バックライトとその部材開発では、 高効率化が大きな課題となっている。

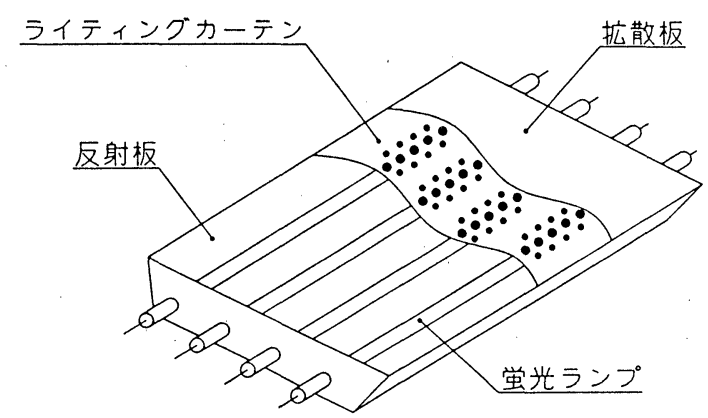

図 2. 直下方式バックライト

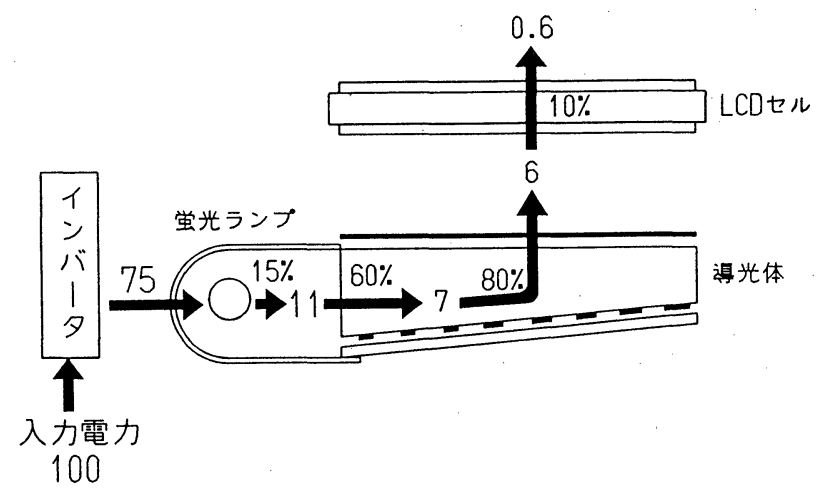

図 3. 導光体方式バックライトのエネルギー効率

\section{7-6-2. 導光体方式バックライトの構成}

ここでは、現在主流となっている蛍光ランプを用いた䆃 光体方式バックライトの構成について述べる。

導光体方式バックライトは、線光源である蛍光ランプを、 裹面にドットパターンを設けた透明アクリル製の導光体を 用いて平面光源に変換する方式である。この方式は、焦炎 ランプを導光体の側面に配置するため薄型化に有利であり、 ドットパターンの密度設計により、輝度均一性の高い平任 光源を得やすいため、ノート $\mathrm{PC}$ を中心としてほとんどの LCD パネルに採用されている。代表的な導光体方式バック ライトを図 4 に示す。 


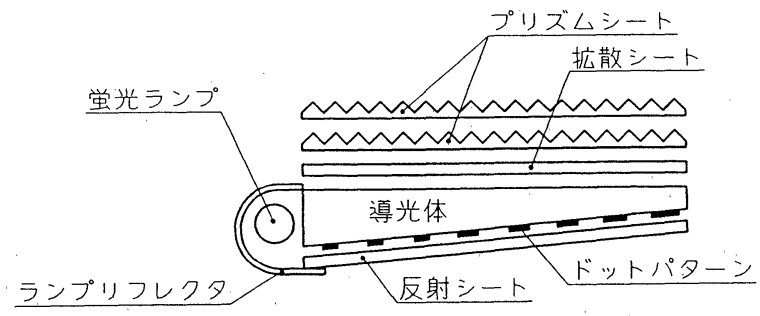

図 4. 導光体方式バックライトの構成

7-6-2-1. 導光体、反射シート、拡散シート

導光体は届折率 1.49 程度のアクリル樹脂で射出成型に より作られ、導光体と空気の届折率の違いによる光の全反 射を利用したもので、厚みは $2.5 \mathrm{~mm}$ 程度である。

導光体はバックライトのなかでほとんどの重量を占める 部品なので、軽量化のため、蛍光ランプ側以外を薄くした ウェッジ形状となっている。

導光体の側面から入射された光は、導光体表裏面での全 反射により終端まで導光する途中で、散乱体であるドット パターンにより一部の光を散乱させて表面に光を取り出す。 ドットパターンをランプから遠ざかるにつれて密度を大き くすることにより、平面的に輝度が均一な光源が得られる。

光を表面に取り出すためのドットパターンは、酸化チタ ン等の白色インクを径 $0.2 \sim 1 \mathrm{~mm}$ のドットとしてスクリー ン印刷する。最近では、白色インクをスクリーン印刷する かわりに導光体自身に細かい凹凸のドットパターンを設け たものも製品化されている。 ${ }^{2}$ この方式では、導光体成型 時にドットパターンも同時に成型されるため、印刷工程は 不要となる。

導光体裏面に漏れた光を再利用するため、反射シートを 導光体裏面に配置し、導光体表面には輝度ムラを緩和する 拡散シートが配置される。

\section{7-6-2-2. 入射光学系}

蛍光ランプからの光は、ランプリフレクタで導光体側面 に集光入射させる。図 5 に導光体厚とバックライト相対輝 度の関係を示す。導光体厚がランプ径より小さくなると急 激に嶕度が低下するのがわかる。これは、反導光体側から 出た监光ランプの光が巣光ランプ自身に遮られ、導光体に 入射しないためである。図 3 に示すとおり、入射光学系で のエネルギー效率は、導光体厚 $3 \mathrm{~mm}$ 、蛍光ランプ径 $2.6 \mathrm{~mm}$ で60\%と非常に低い。

したがって、蛍光ランプから出た光を導光体に有効に入 射させるためには、導光体厚を大きくすればよいが、薄型、 軽量化の要求に矛盾するため、蛍光ランプの細径化で光入 射效率の低下を補うとともに薄型化を実現している。

薄型化により、蛍光ランプから導光体への光入射効率が さらに小さくなるため、今後は入射光学系での技術開発が 非常に重要である。

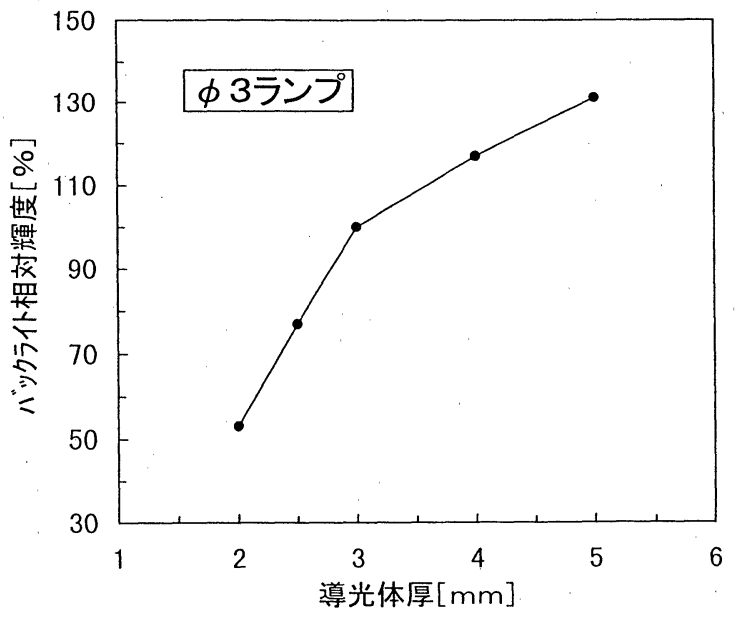

図 5. 導光体厚によるバックライト相対輝度特性

7-6-2-3. プリズムシート

プリズムシートを拡散シートの上に置くと、レンズとし て働き出射光に指向性を与え、LCD 正面の輝度を高くする ことができる。ノート PC 等では、LCD 画面はほぼ正面か らしか見ないので、実用上、同じ消費電力で明るい画面を 実現できる。

ポリエステルやポリカーボネイト等で作られ、厚さ 140 $\sim 250 \mu \mathrm{m}$ 、ピッチ $24 \sim 100 \mu \mathrm{m}$ 、頂角 $80 \sim 100^{\circ}$ 、形状 は三角形から蒲鉾形までさまざまな種類がある。輝度向上 において理想的な頂角が $90^{\circ}$ のプリズムでは、1 枚使用で 約 1.5 倍、 2 枚では 2 倍以上の正面輝度向上を実現できる が、配光特性（半值全幅）は $50^{\circ}$ 以下となり、正面からは 明るいが、斜め方向からでは暗い画面となってしまう。威 6 に代表的な配光特性を示す。

現状では、プリズムシートは高価な部材であり、2 枚使 用するとバックライトの価格は約 1.5 倍となってしまうた め、輝度を維持したままプリズムシート枚数を削減する開 発が盛んに行われている。

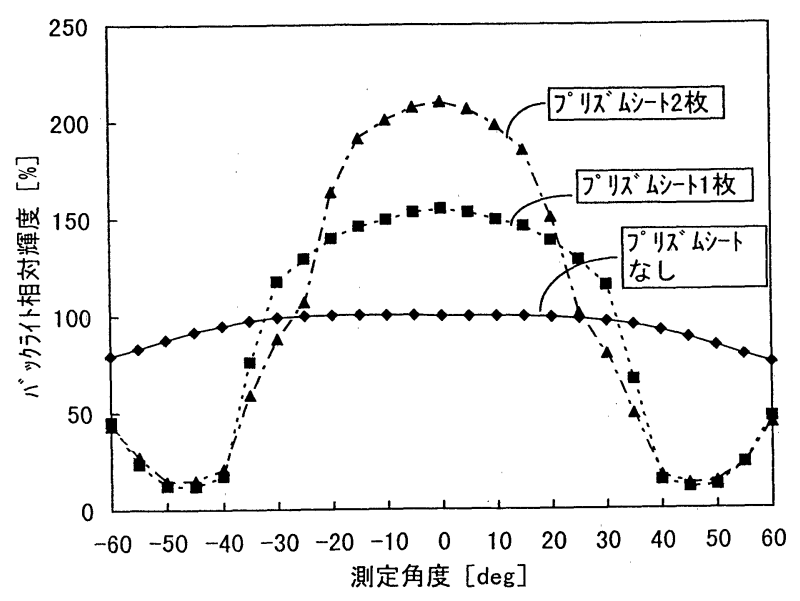

図6.プリズムシートによる配光特性 


\section{7-6-2-4. 蛍光ランプ}

蛍光ランプは、直線型の冷陰極方式蛍光ランプが用いら れ、径 $2.2 \sim 2.6 \mathrm{~mm}$ が主流であり、最近の薄型 LCD モジ ユールでは径 $2 \mathrm{~mm}$ が採用されている。

一般照明用として広く用いられている熱陰極方式䖺光う ンプは効率が良く高輝度が得られるが、電極構造上、 $4 \mathrm{~mm}$ 以下の細径化が困難であり寿命が短い(約 5000 時間)。LCD モジュール用としては細径化が可能で長寿命 ( 1 万〜 4 ) 時間）の冷陰極方式蛍光ランプが使われている。

発光効率は、細径化を中心とし、蛍光体の可視光への変 換效率の向上、電極材料による陰極降下電圧の低減、封人 ガスの最適化等で改善されてきた。図 7 にランプ内径によ る発光効率特性を示す。細径化により、蛍光ランプの発光 効率は向上していくが、内径 $2 \mathrm{~mm}$ （外径 $2.4 \mathrm{~mm}$ ）でほぼ ピークを示し、それ以下では減少していく。 ${ }^{3}$ 内径 $1.6 \mathrm{~mm}$ （外径 $2 \mathrm{~mm}$ ）までの細径化による蛍光ランプ自体の発光 効率低下分は、前述の導光体への光入射効率向上効果で相 殺されるため、バックライトとしての効率低下に至らない。

しかし、今後の薄型化要求により、内径 $1.6 \mathrm{~mm}$ (外柊 $2 \mathrm{~mm}$ ）以下が必耍となるため、さらなる改善アイテムが必 要である。

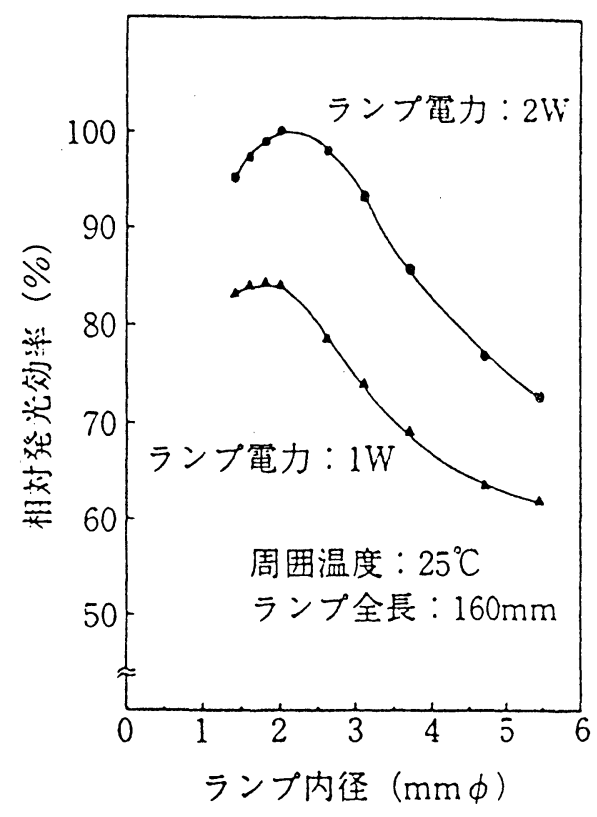

図 7.ランプ内径による発光効率特性

7-6-3. これからのバックライト

ノート PC の分野では、さらなる薄型や軽量化、低消监 電力化が必要である。

しかし、現在ディスプレイの大半を占めているのは CRT (CRT: Cathode Ray Tube) モニタである。近年では、LCD モジュールが薄型、軽量である特徽を生かし、CRT モニタ の置き換えとなる大型 LCD モ二夕の開発、製品化も盛ん である。
モニタ用途では、高耀度、広視野角が要求されるため、 バックライトはノート PC 用途とは異なった視点から開発 が必要となる。

さらに、ノート PC 用途、モニ夕用途でのよりいっそう の普及、他の応用分野への展開を図るためには、低価格化 が必須条件となる。

これからのバックライトに求められる性能と、それらに 対応するバックライト、部品・材料分野での新しい提案例 を以下に紹介する。

\section{7-6-3-1. 成型プリズム導光体バックライト}

図 8 のように、導光体裏面に細かい凹凸形状と、表面に はプリズム状の形状を射出成型によって形成することによ り、導光体にプリズムシートの機能を持たせ啭度を高める 効果が確認されており、小型のバックライトでは実用化が 始まっている。2 12.1 インチクラスでのプリズムシート枚 数削減による低価格化が期待される。

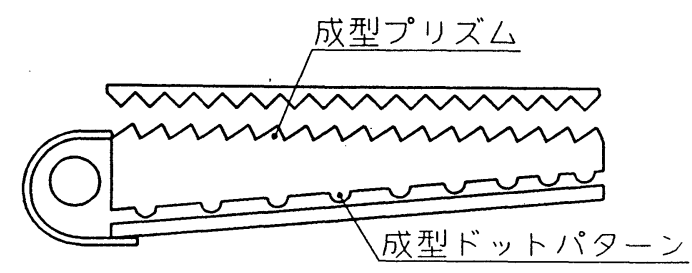

図 8. 成型プリズム導光体バックライト

\section{7-6-3-2. 光散乱ポリマー導光体バックライト}

導光体アクリル樹脂内に屈折率の異なる材料を分布させ た光散乱ポリマー導光体を用いることで、光の多重散乱を 利用し、ドットパターンと拡散シートが無くても均一な平 面光を得られるバックライトである。表面に出射する光は 導光体表面の法線に対し斜め方向に指向性のある分布を持 つため、図 9 のように出射光を導光体表面法線方向に補正 するプリズムシートが必要である4

この方式も、プリズムシート枚数の削減、拡散シートの 削除による低価格化が望まれる。

\section{7-6-3-3. 偏光バックライト}

従来ではバックライトから出た光の約半分は LCD セル の偏光板に吸収されていた。

図 10 のように偏光分離シートをバックライト表面に配 置することにより、バックライトから出た光のうち LCD セルの偏光板と同一の偏光成分だけを透過させ、直行する 偏光成分はバックライト側に戻して無偏光化し、再び LCD セルの偏光板と同一の偏光成分のみ透過させる。この光の 再利用の繰り返しにより、バックライトから出た光をほぼ 全て LCD セルに入射させることができる。 
この方式では、プリズムシートのように光に指向性を与 えることなく耀度を向上できるため、広配光 (広視野角) 特性、高輝度が求められる大型モ二夕用途吕ら実用化が始 まっている。

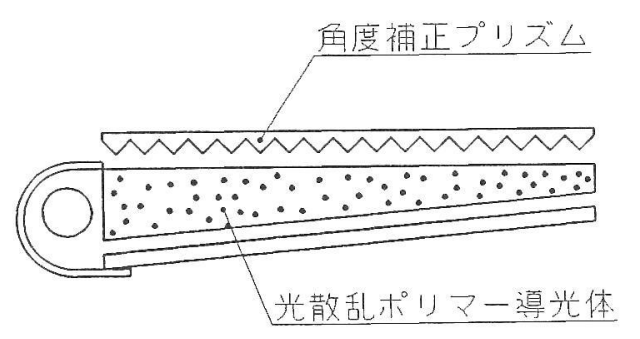

図 9.光散乱ポリマー導光体バックライト

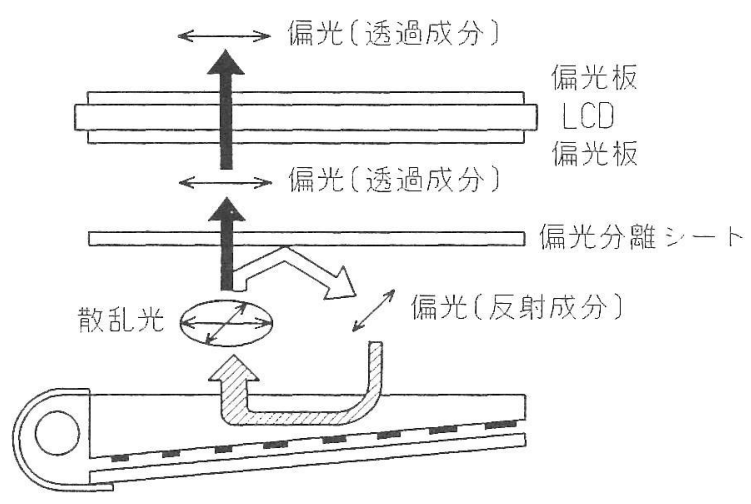

図10.偏光バックライト

7-6-3-4. 中空バックライト

図11のように、光制御導光体とプリズムレンズアレイ を用いて、空気中で光を伝播する方式が開発されている。

20 インチクラスのバックライトを、導光体方式で作る と $2 \mathrm{~kg}$ 以上となるが、中空バックライトでは約半分の重量 を実現できる。大型 LCD モニタやテレビ用での、整量化 の方式として期待される。

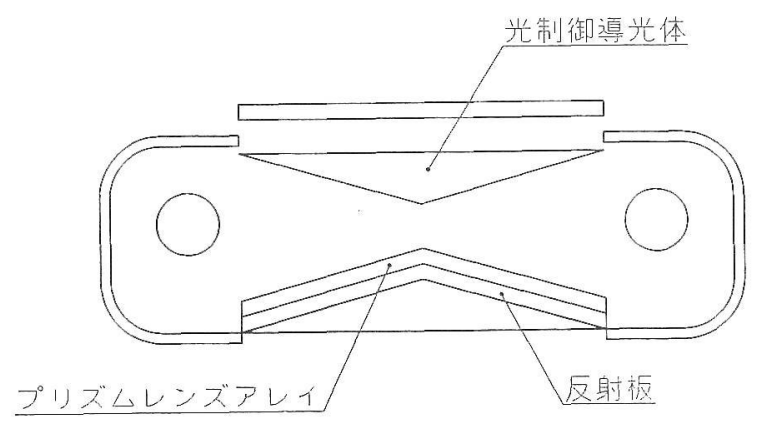

図 11 . 中空バックライト

\section{7-6-4.お打りに}

LCD 用バックライトは、ノート PC 向村を中心に、多く の方式、部品材料が提案され、寒用化および改良さ㧈てき た。

今後も、ノ一ト PC 用途では薄型・軽量・低消費電力。 低価格化、モ二夕用途では大面面・高阽度・広配光・低価 格化、さらに他分野への展開に向けて、技術開発を進好 いかなければならない。

バックライトメーカ、部品材料メーカとの連携をさらに 強め、市場要求を先取りした開発を進めていきたい。

(次号に続く)

\section{参考文献}

“木村博一、“バックライトシステム”、OplusE，(株）新技 術コミュニケーションズ、1997年 2 月号、pp.108-104.

”佐藤光世、“導光板、プリズムシート、陰極管など部品 レベルで開発競争が熾烈するバックライト”月刊 LCD Intelligence、プレスジャーナル社、1997 年 11 月号、pp.61-64. “野口英彦、“液晶バックライト用冷陰極営光ランプの技 術動向”、月刊ディスプレイ、テクノタイムズ社、1996 年 5 月号、pp40-45.

“堀部晃啓、小池康博 他“光散乱ポリマー導光体の LCD 用バックライトへの応用”、電子情報通信総合大会予稿、 C-25,p.117 (1995).

”高橋健太郎、田中直樹、“プリズム一体化導光板や偏光 分離フアイルを採用、新バックライトが本格化”日経マイ クロデバイス、日経 BP 社、1997年6月号、pp.160-161.

"田中章、“大型中空式バックライト”、第 7 回ファインブ ロセステクノロジー・ジャパン 97、C5、高輝度化、薄型 化にとりくむ LCD バックライト、1997 年 7 月 4 日開催、 pp.4-10 (1997).

著者紹介：橋本 健(はしもとたけし)

(株) 東芝 液晶事業部

モジュール設計技術部

モジュール設計第二担当

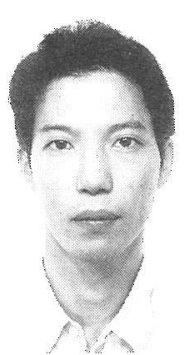

